\title{
Assessing Three-Dimensional Art Objects Quantitative Evaluation of Qualitative Achievements in Art and Design Education
}

\author{
Nedina Sari \\ Faculty of Art \& Design, Institut Teknologi Bandung, \\ Jalan Ganesa No.10 Bandung 40132, Indonesia \\ Email: nedina_sari@fsrd.itb.ac.id
}

\begin{abstract}
Knowledge about shaping three-dimensional objects is tangibly and conceptually relevant to human activities within a spatial environment, and is part of formal arts and design education as one of the basic elements in the process of learning about creating functional artifacts and art objects. Basic skills connected with this knowledge are conveyed in 'Basic Three-Dimensional Object' class, which is aimed at conveying a deeper understanding of threedimensional objects as touchable and visible, and occupying a structural space. Learning this entails is quite an elaborate exploration, which, when evaluated afterward, is of a qualitative nature. However, in higher education every step of the learning process is quantified in order to validate the students' achievements. This requires an objective judgment from the lecturer, despite the fact that many parameters which are relevant for art objects are not exact. Therefore, once grades are released, not all students understand the meaning of numbers that represent their grades. These numbers are of a precise, quantitative nature, while explanations from lecturers in non-exact narrations are of a qualitative nature. The contrast between these two types of evaluation has raised questions such as: is quantitative grading an appropriate method, or is it better to use a subjective validation to appreciate creativity?
\end{abstract}

Keywords: art \& design; education; form; nirmana; 3D object Introduction.

\section{$1 \quad$ Introduction}

In art and design education, studying two-dimensional and three-dimensional forms, either in the form of a measurable object or the spatial environment around human activities, is one of the foundations of creating functional artifacts or art objects. Basic skills connected with this knowledge are conveyed in 'Basic Three-Dimensional Object' class.

\section{Discussion and Analysis}

The objective of the class is to convey a deep understanding that threedimensional objects are touchable, visible, and occupies a structural space

Received November $27^{\text {th }}, 2009$, Revised October $29^{\text {th }}, 2013$, Accepted for publication November $8^{\text {th }}, 2013$. Copyright (C) 2013 Published by LPPM ITB, ISSN: 1978-3078, DOI: 10.5614/itbj.vad.2013.4.1.3 
(length, width and height). To form a three-dimensional object, formal elements such as frames, structures, texture, color, distance, etc. are composed according to formal harmony (balance, proportions, and structural rhythm) using assigned materials. This class aims to drill student's capability of constructing a threedimensional object (or a certain structure that occupies space) without embedding any functions or interpretative symbolizations. Thus, this class is also titled "Nirmana Tiga-Dimensi", which literally means "a three-dimensional object with nothing-implied" - a three-dimensional object with no conceptual or interpretative attributes besides formal discourse (see Figure 1).

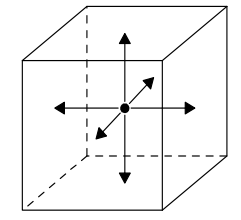

(a)

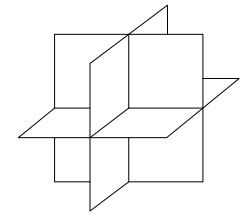

(b)

Figure 1 Studying three-dimensional objects aims to build the understanding towards subjects of form creation that the objects they make may exist within a certain space; felt, grasped, or that the subject is within the three-dimensional object. This is in line with Aristotle's "topos" theory which defines form as within the view of the subject; or, if the subject is within the form, then the form is defined as space.

The education means applied by this class refers to the Western means of education. After more than 20 years since it was first applied in Indonesia, namely the Faculty of Art \& Design, Bandung Institute of Technology, the methodology of art \& design basic education by Bauhaus is still the method of conveyance applied by this class. According to Bauhaus, creative inspirations are sparked through pragmatic experimentations of the object of study.

Most of the class' subjects refer to natural shapes or surrounding objects: it demands students to examine underlying basic forms from surrounding objects and transfer its formal essence into studied materials. This phase is applied after students are prepped with the introduction and understanding of the studied material's characters. Students will be asked to form a three-dimensional object by applying the formal essence they harness into the materials they are assigned to use.

Forming basic objects in reality is more difficult than designing products, designing rooms, or producing artworks. Designing products, rooms, and producing artworks are done within the framework of a certain concept. In designing products, ergonomic conceptions define the attribute one product. 
The size of a shoe, for example, can not be too big or too small for the designed shoe to become a functionally ergonomic product. A partition wall that's too high will create a claustrophobic sensation to people inside the room. Designing a chair requires designers to consider which material is best to provide comfort, how the material will be processed, as well as the necessity of the chair's user. These considerations work as a framework to guide designers in achieving the most optimal result, which is to provide a best solution for the issue of whereto-sit-comfortably. Also, in creating a painting, artists try to achieve the most aesthetic images to provide viewers with the loveliest sensation when seeing the painting so it can be sold with a high price. Or, the artist intends to create ugly, disturbing, and scary images because the artist wants to convey a dark or critical concept. This can be seen in many installation artworks, for example, which contains a message for the society to discuss about.

Forming basic objects, as would like to be achieved by Basic ThreeDimensional Objects class (Nirmana Tiga-Dimensi) works through aesthetic reasons which are declared visually (See Figure 2). Students are expected to understand structural limitations of the assigned materials which halts the growth of a certain structure. Generally, decisions regarding size and proportions of the dimension are made through the guidance of lecturers and teaching assistant, since at this stage of creation, it is impossible to eternally develop a studied structure without stopping at one point. At a certain point, a stop signal is conveyed also by lecturers and teaching assistant based on their credible experience on processing aesthetical forms, an experience yet to be possessed by students. The stop signal will be conveyed at the most appropriate stage of one student's formal exploration.
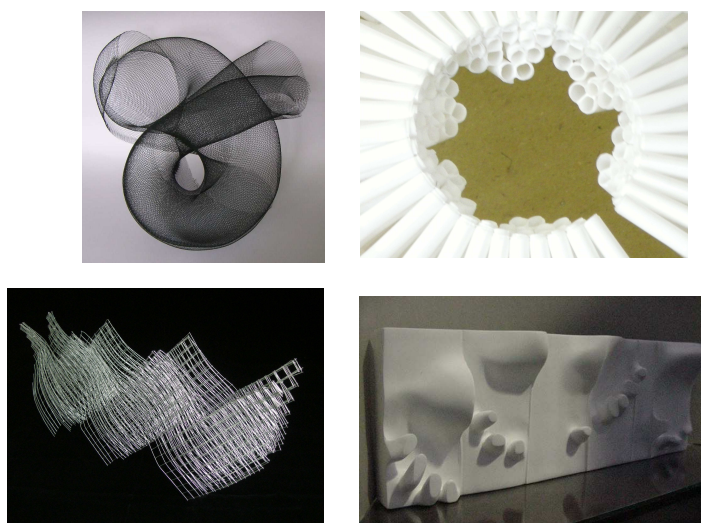

Figure 2 Several students trainings in Nirmana Tiga Dimensi which the stopping logarhythmic growth or repeated arrangement of form. 
Aside from structural growth, formal development also involves either recursive duplication, a process in which one module is identically replicated continuously; or iterative duplication, where a certain formation or arrangements of different shapes is being repeated. Lecturers and teaching assistants will still take a considerable role in deciding which duplication process should be applied to student's developing form.

Formal development, as seen in natural objects, has the ability to stop itself then bestows to us a certain unique aesthetic value. In the case of human creations, the decision of stopping the formal development is taken after considering aesthetic experience and a thorough comprehension about the limits of a certain material.

It is a fact that some artistic objects in the nature grow and develop according to a certain mathematical rule or conception. For example, some natural developments work under the Fibonacci Number; a numerical sequence named after Fibonacci, an Italian mathematician. A number in the Fibonacci sequence is the sum of the two numbers that precedes it (see Figure 3). Another example of the rule of natural growth is the "Golden Ratio", the pristine balance of proportion, as contained in the bodily proportions of a human being or the ratio of our fingers' segments (see Figure 4). These rules have apparently been applied by ancient artists and architects since a very long time, notably in the construction of the Great Egyptian Pyramids and the painting, "Mona Lisa".

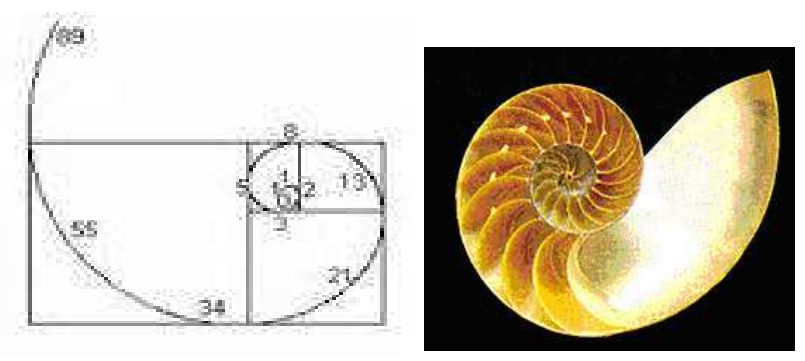

Figure 3 Demonstrates the logarhythmic growth of a nautilus' shell, consistent with the Fibonacci sequence, while separated into segments by walls formed by pearl-like calcium. These process shows a duplication of shell-segments while growing in size, advancing into bigger space while leaving a pearly partition behind. At a moment of best proportions, the growth will stop instead of continuing an excessive spiral. 


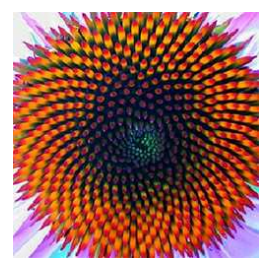

Figure 4 Similar pattern is observed in the seeds of a sunflower. This pattern is defined as "gnomic growth", a balance pattern of nature defined by biologist Sir D'Arcy Thompson. The biologist stated that it is impossible to conjure a simpler system during a shell's growth other than a system where the growth in width and length follows a constant ratio. This system allows the shell to continuously grow while keeping its initial spiral form intact.
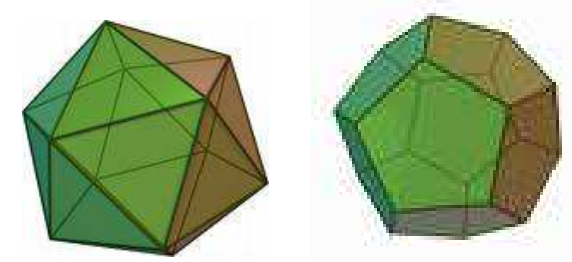

Figure 5 An icosahedron is formed by 20 equilateral triangles, while a dodecahedron is formed by 12 planes of equilateral pentagons.

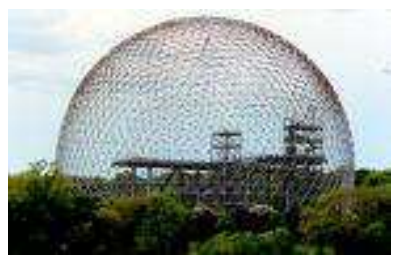

Figure 6 R. Buckminster Fuller's dome.

Three-dimensional shapes attributed with the Golden Ratio can be found in many types of microorganism. Many viruses takes shape of icosahedrons and/or dodecahedrons (see Figure 5). One of the most notable is the Adeno virus. The protein shell of this virus consists of 252 protein subunits, all of them arranged uniformly with flexibility inside. 12 protein sub-units in the angles of the icosahedrons forms a pentagonal prism. This concept is the muse to the design of a complex and elaborate dome by R. Buckminster Fuller (see Figure 6). One of the smallest living beings possesses in its bodily composition a perfect design, much more ornate than the design of Buckminster Fuller, one of the world's best architects. 
Many objects in nature show that they are arranged through proportional measures, able to be conveyed narratively as a quantified object. The repetition and growth of a certain form has to be limited into a certain number of repetitions until the moment where the growth should end, so as not to eternally duplicate. Remarks like "aesthetically adequate", "excessive", or "vulgar" are qualitative comments often used to appreciate the value of the artwork.

The next step of forming basic objects is the appreciation and feedback conveyed by lecturers towards the formed artwork; as a mean to parametrically compare the many artworks produced by students. The output gained by students as artwork creators is a score (a number or a letter) representing the quality of each artwork. Generally, artworks, as assignments, are appreciated through qualitative appreciations. Remarks like "nice", "good", "beautiful", "proportional", "balanced" and many others are qualitative remarks as they are results of a subjective judgment collectively determined by several appreciators. However, it is difficult to rely upon one or two individuals' subjective judgment in order to achieve quite an objective result. Understanding and appreciation towards one artwork would be likely to differ one individual to another, while those remarks would have to be concluded into a measured, quantified score. In order to provide an effective education, it is necessary to have accurate positioning of an artwork's quality that is generally understood by appreciators, especially by students as creators of those artworks.

\section{$3 \quad$ Results}

From the aforementioned procedure, several concepts clash. The process of getting ideas from natural and surrounding objects is a quantitative process; the instinctive mean of appreciation is a qualitative process, but the appreciation has to be translated into a quantified statement. Thus, when translating qualitative appreciation into a quantified statements, several specific frameworks have to be applied as parameters that are representative to appreciation, which has to include not only measurements of aesthetical elements embodied in the artwork, but also narrating the essence and aura of the artwork.

Nature, that has become the source of ideas in the process of discovering forms, has limited the forms without certain formulas or borders that are hard to quantify. During the process of decision making by lecturers and their students in discovering forms in a Three Dimension Nirmana class, occurrences that cannot be quantifiably described are apparent. Therefore, when the forms emerge and become, what are visible and sensed are the values of a certain form, which then can be graded qualitatively, or can only be presented in narrative. A description containing several sentences laid out the conceptual 
values of the form that are achieved by the training. Therefore, when the evaluative statement has to be presented in an alphabetical or numerical qualification, that statement is a conclusion that has to be formulated simultaneously by several instructors/lecturers through an argumentative process, in order to make a decision upon a grade.

\section{Conclusions}

The establishment of such system has led to a classification of grade spectrums. There are works that are classified into AB grade, or B, or BC. There is also another variety of grading, such as works that are classified into 75 , or 80 , or 85 . Sometimes the grades in between, such as 74,76 , or $79,82,84,86$ and so on, show a nuance of qualities that is hard to be determined by the instructor/lecturer team. Therefore, the final alphabets or numbers are actually an attempt to represent a qualitative value as a quantitative one, although qualitative decisions always play a part in the value determination.

\section{References}

[1] Alumni, Ikatan Alumni Institut Teknologi Bandung. 1995. Mengenang Perintis Seni Rupa Indonesia, Penerbit ITB, Bandung.

[2] Corbusier, L. 1973. The Modulor, Faber \& Faber Limited, London.

[3] Grillo, P.J. 1973. Form Function \& Design, Dover Publications Inc. New York

[4] Maier, M. 1977. Basic Principles of Design, Van Mastrand Reinhold, New York.

[5] Margolin, V. \& Buchanan, R. (ed). 1996. The Idea of design, The MIT Press, Cambridge, Massachusetts, London.

[6] Michael, C.T. 1993. Redefining Design from Form to Experience, Van Mastrand Reinhold, New York.

[7] Nagy, L.M. 1956. Vision in Motion, Paul Thebalt \& Company, Chicago.

[8] Santosa, I. 1994. Telaah Kritis Konsep Ruang Arsitektur Interior Bauhaus, Thesis Program Pasca Sarjana, Program Studi Seni Rupa \& Desain, ITB, Bandung.

[9] Sutrisno, M. 2005. Teks-teks Kunci Estetika-Filsafat Seni, Galang Press, Yogyakarta.

[10] White, F. 1991. Bauhaus, Thames \& Hudson Inc., London.

[11] Widagdo. 2005. Desain \& Kebudayaan, Penerbit ITB, Bandung.

[12] William, C.G. 1981. Origins of Form, Architectural Book Publishing Company, New York. 